研 究

\title{
湿式造粒処理を施したアルミニウム合金粉末の圧密化挙動解析
}

\author{
近藤 勝義山1, 武田 義信的 ${ }^{1}$, 渡辺 龍三蚛, 橋本 等的 3

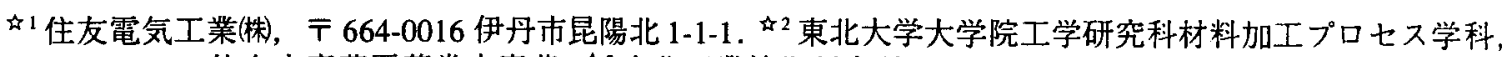 \\ 干 980-8579 仙台市青葉区荒巻字青葉。 和東北工業技術研究所， 广 983-8551 仙台市宮城野区若竹 4-2-1.
}

\section{Analysis of Compaction Behavior of Wet Granulated Aluminum Alloy Powder}

\author{
Katsuyoshi Kondoh ${ }^{\not 1}$, Yoshinobu Takeda ${ }^{\not 1}$, Ryuzo Watanabe ${ }^{\not 2}$ and Hitoshi Hashimoto \\ ${ }^{4}$ I Sumitomo Electric Industries Ltd., 1-1-1 Koya-kita, Itami 664-0016. «2Dept. Materials Processing, Graduate School of Eng., \\ Tohoku University, Aoba-ku, Sendai 980-8579. ${ }^{3}$ Tohoku National Industrial Research Institute, Materials Engineering Division, \\ Materials System Section, 4-2-1, Wakatake, Miyagino-ku, Sendai 983-8551.
}

Received December 14, 1998

\begin{abstract}
SYNOPSIS
Compaction behaviors of wet granulated aluminum powder were examined by uni-axial die compaction and effects of rearrangement and plastic deformation on them were analyzed by using Cooper-Eaton equation. Based on calculation results and structure/morphology of granulated powder, new compaction model for granulated powder, which consists of three compaction mechanisms; macro-rearrangement, micro-rearrangement and plastic deformation, and modified equation were proposed in this study. It indicated that a macro-rearrangement was a dominant factor on compaction behavior of granulated powder and the modified equation was adaptive enough to analyze compaction behavior.
\end{abstract}

KEY WORDS

PVA binder, Granulated powder, Flow ability, Apparent density, Compaction behavior, Cooper-Eaton equation, Macro-rearrangement, Micro-rearrangement, Plastic deformation

\section{1 緒 言}

微細な急冷凝固組織を有する焼結アルミニウム合金は溶製 合金に比べて優れた機械的特性および耐摩耗性を発現するこ とから小型軽量化が望まれる自動車用部品への実用化が検討 されている゙.また焼結材の部品化に際して, 粉末成形体にお ける密度分布の均一化は機械的特性の向上のみならず焼結体 の高寸法精度化の観点からも重要な課題である。一方、アル ミニウム合金粉末は鉄系粉末に比べて低比重・微細粒径・異 形状などの理由によって難流動性・難充填性を示すため, 高 寸法精度の成形体を得ることが困難である。これに対して， 著者らは前報”で PVAバインダーを用いた湿式造粒法により アルミニウム合金粉末の流動性を改善することで成形体の寸 法ばらつきを低隇できることを明らかにした.しかしながら， このような造粒粉末を用いた成形体における密度分布の均一 化においては，造粒粉末の圧縮機構を正確に把握し，圧縮特 性を制御する因子を明らかにする必要がある。これまでに橋 本・渡辺ら ${ }^{31}$ は鉄系粉末の圧密化挙動を明らかにするため, 粉 体の圧縮成形過程が粒子の再配列・塑性変形・破砝など幾つ かのプロセスから成り，それぞれの確率過程論に基づいて指
数関数として定式化されるとしたCooper-Eaton"の圧縮式を用 いて解析を行なっている.

そこで本報では，湿式造粒アルミニウム合金粉末の圧密化 挙動を解析することを目的に，その粉体特性に基ついて造粒 粉末の圧密化モデルと Cooper-Eaton 圧縮式を基調とした修正 式を提案し，これを用いて造粒粉末の压密化機構に及ほす粉 体特性の影響について検討した。

\section{2 実験方法}

2.1 造粒アルミニウム合金粉末の特性

ここでは，前報と同様に転動式造粒装置により平均粒子径 $47 \mu \mathrm{m}$ のアルミニウム合金粉末 (公称組成; Al-12Si-2Ni-1 Mg/ mass\%) を PVA (Polyvinyl Alcohol) 水溶液を用いて湿式造粒処 理したものを試料粉末とした. Table 1 に造粒工程で用いた PVA バインダーの濃度および原料粉末 $1 \mathrm{~kg}$ に対する添加質量 および造粒粉末中のPVA 質量分率を示す，またTable 2 に各 粉末の粉体特性を示す.

2.2 粉末の圧縮成形方法

圧粉成形過程に掞ける粉末の圧密化挙動の圧力依存性を評 
Table 1 Conditions of PVA binder used in wet granulation.

\begin{tabular}{cccc}
$\begin{array}{c}\text { Sample } \\
\text { No. }\end{array}$ & $\begin{array}{c}\text { Concentration of PVA binder } \\
\text { (\%) }\end{array}$ & $\begin{array}{c}\text { Amount of PVA binder } \\
\text { (mass\%) }\end{array}$ & $\begin{array}{c}\text { PVA mass fraction } \\
\text { (mass\%) }\end{array}$ \\
\hline \hline 1 & 2.0 & 7.5 & 0.15 \\
2 & 2.0 & 10.0 & 0.20 \\
3 & 2.0 & 15.0 & 0.30 \\
\hline 4 & 3.0 & 7.5 & 0.225 \\
5 & 3.0 & 10.0 & 0.30 \\
6 & 3.0 & 15.0 & 0.45 \\
\hline 7 & 4.0 & 7.5 & 0.30 \\
8 & 4.0 & 10.0 & 0.40 \\
9 & 4.0 & 15.0 & 0.60
\end{tabular}

Table 2 Characteristic of granulated aluminum alloy powder.

\begin{tabular}{ccc}
$\begin{array}{c}\text { Sample } \\
\text { No }\end{array}$ & $\begin{array}{c}\text { Average particle } \\
(\mu \mathrm{m})\end{array}$ & $\begin{array}{c}\text { Apparent density } \\
\left(\mathrm{Mg} / \mathrm{m}^{3}\right)\end{array}$ \\
\hline 1 & 74.8 & 0.772 \\
2 & 85.8 & 0.694 \\
3 & 94.1 & 0.615 \\
\hline 4 & 76.5 & 0.751 \\
5 & 90.4 & 0.701 \\
6 & 99.0 & 0.624 \\
\hline 7 & 77.7 & 0.823 \\
8 & 92.4 & 0.798 \\
9 & 102.1 & 0.738
\end{tabular}

価すべく，本実験では25ton万能式圧縮試験機にセットした成 形用金型 (内径; $\phi 11.3 \mathrm{~mm}$, 型材質; 超硬) 内に試料粉末 $2 \mathrm{~g}$ を 充填して圧粉成形を行なった，但し，ステアリン酸亜鉛を溶 解したアセ卜ン溶液を潤滑剤として金型の内壁および上下パ ンチに塗布し，乾嬠後に粉末を充填した．圧縮時の加圧速度 を $0.5 \mathrm{~mm} / \mathrm{s}$ 一定とし，压縮過程において粉末に作用する荷重 および上パンチの変位量の関係を測定してその圧縮変位量か ら成形体体積の隇少量を算出した，そして抆出し後の成形体 の全長捛よび直径から成形体の体積を求め, この值が金型内 での最大加圧下での粉末体積と同一であると仮定して，先に 測定した成形体体皘の隇少量を加算することで各成形圧力と 成形体体積との相関 (圧力 $\mathrm{P}$ 一容皘 $\mathrm{V}$ 曲線) を求めた. 粒子再 配列機構の影響を箃密に評価するためには，可能な限り低圧 力条件での圧縮変位量を測定することが有効であることから 本実験では最小荷重を $98 \mathrm{~N}$ と, 最大荷重 $78 \mathrm{kN}$ に設定した。 なお，比較として造粒処理を施さない1次粒子原料粉末につ
いても同様の方法で圧縮特性を評価した.

2.3 Cooper-Eaton 式による粉末の圧密化挙動解析方法

ここでは, (1)式に示すように粉末を金型内で圧縮成形する 際の圧密化機構を粒子の再配列による体積隇少と粒子の塑性 変形および破砝による体積減少から成ると仮定し, 確率過程 論に基づいて2項の指数関数の線形式として表現したCooperEaton 式を用いた。

$$
\begin{gathered}
\mathrm{V}^{*}=\frac{\mathrm{V}(0)-\mathrm{V}(\mathrm{p})}{\mathrm{V}(0)-\mathrm{V}(\infty)}=\mathrm{al} \exp (-\mathrm{k} 1 / \mathrm{P})+\mathrm{a} 2 \exp (-\mathrm{k} 2 / \mathrm{P}) \\
\mathrm{a}, \mathrm{k} 1 ; \text { Coefficient of rearrangement } \\
\mathrm{a} 2, \mathrm{k} 2 ; \text { Coefficient of plastic deformation } \\
(\mathrm{a} 1+\mathrm{a} 2=1)
\end{gathered}
$$

ここで, $\mathrm{v}(0)$ は無加圧状態での粉末の充填容積であり本実騃

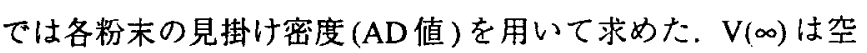
隙が存在しない状態での粉末容積であり，秤量した試料粉末 の質量と真密度から算出した. 右辺第 1 項は粒子再配列に上 る体積圧縮率，第 2 項は粒子の塑性変形々破研現象による体 積圧縮率に相当する．ａ１およびa 2 はそれぞれ極限圧力付加状 態 $(\mathrm{P} \rightarrow \infty)$ における各圧密化機構による体積圧縮率を意味し ており，例えば, a1が a 2 よりも大きい場合は粉末の全体皘压 縮量に占める粒子再配列の奇与度が大きいことを示唆してい る.また $\mathrm{k} 1, \mathrm{k} 2$ は各圧密化機構の開始相当圧力を表しており, その值が大きいほど高い圧力条件下でその圧密過程が生じる ことを表わしており，k1が大きくなるにつれて粒子再配列に よる圧密化機構が起こり難くなることを意味する。そして本 実験では，圧縮試験により得られた圧力 $\mathrm{P}$ 一容皘 $\mathrm{V}$ の相関 データから非線形最小2乗法によって式中の各定数(al, k1, a2, k2)を算出し，これらを用いてそれぞれの圧密化機構による体 皘圧縮率の棇和 $V^{*}\left(0 \leqq V^{*} \leqq 1\right)$ を算出する。，その結果, 粉末 の圧縮特性の成形圧力依存性および緻密化過程での到達圧密 率を定量的に把握できる。 


\section{3 実験結果および考察}

3.1 造粒粉末の圧密化挙動解析結果

先ず，粒子再配列機構の奇与度パラメー夕 al と造粒粉末の $\mathrm{AD}$ 值の関係を Fig.1 に示す。造粒粉末を用いた場合の $\mathrm{a} 1$ 值は 原料粉末に比べて増加しており，その值は $\mathrm{AD}$ 值の増加に対 してほほ直線的に滅少している。これは $\mathrm{AD}$ 値の小さい粉末 を金型内に充填すると粉末間の空隙量が增加するため，圧密 化過程において粉末が移動し易くなり粒子再配列機構の寄与 率が大きくなったものと考えられる.またFig.2に示すように 原料粉末および $\mathrm{AD}$ 值の異なる造粒粉末における圧縮試験時 の圧力一圧縮変位量の関係において，成形圧力が $100 \mathrm{MPa}$ 程 度迄の比較的低い加圧領域での圧縮变位量は原料粉末に比べ て造粒粉末が大きく，造粒粉末の AD 值が小さくなるに連れ てその值は增加している。これらの結果から圧密過程の比較

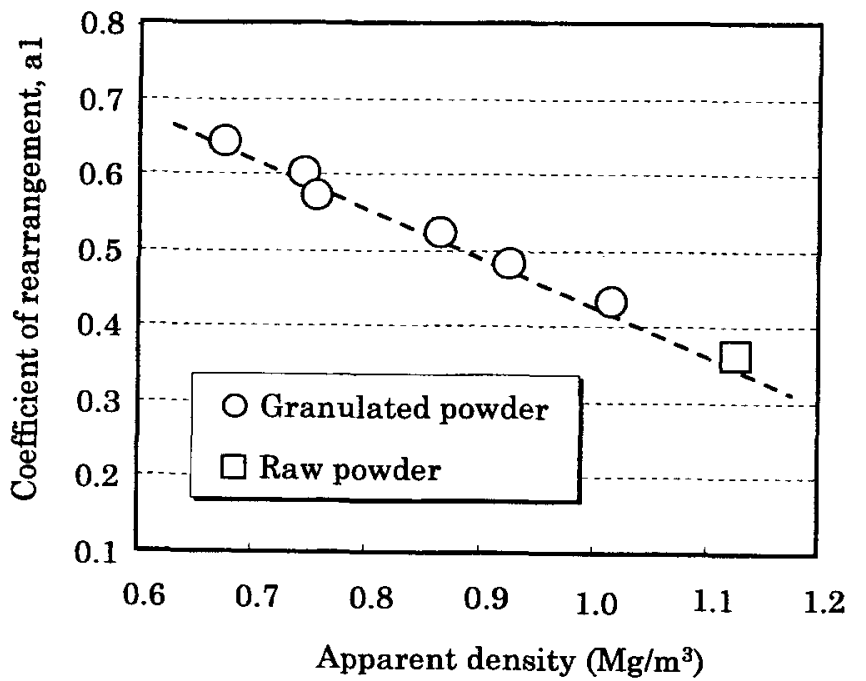

Fig.1 Dependence of coefficient of rearrangement calculated by conventional Cooper-Eaton equation on apparent density of powder.

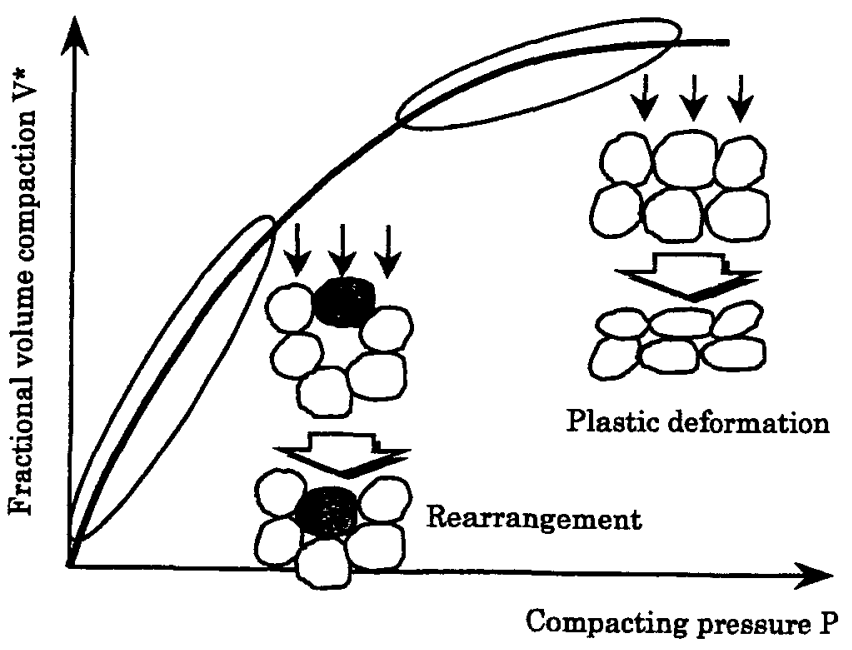

(a)
的初期段階においては，充填時に生じた粉末間の空隙と前報 で示したような造粒粉末内部に存在する空隙を埋めるように 造粒粉末自身およびそれを構成する1次粒子粉末が移動・再 配列することで压密化現象が進行すると考えられる。

以上の結果に基づき，圧縮過程における造粒粉末の圧縮举 動はFig.3に示すような圧密化モデルにより進行すると考えら れる。なお，(a) は従来から提案されている金属粉末の圧密化 過程を表現した模式図であり，(b)が今回提案した圧密化モデ ルである。単一金属粉末においては(a)に示すように，低圧力 域では粒子の移動・再配列によって粒子間の空隙が埋められ る現象が主として生じ，高圧力域では粒子の塑性变形や破砕 によって粒子同士の接触点付近の比較的狭い空隙が埋められ る現象が支配的となる。これに対して造粒粉末の圧密化挙動 は(b)に示すような機構によるものと推察される.粒子の塑性

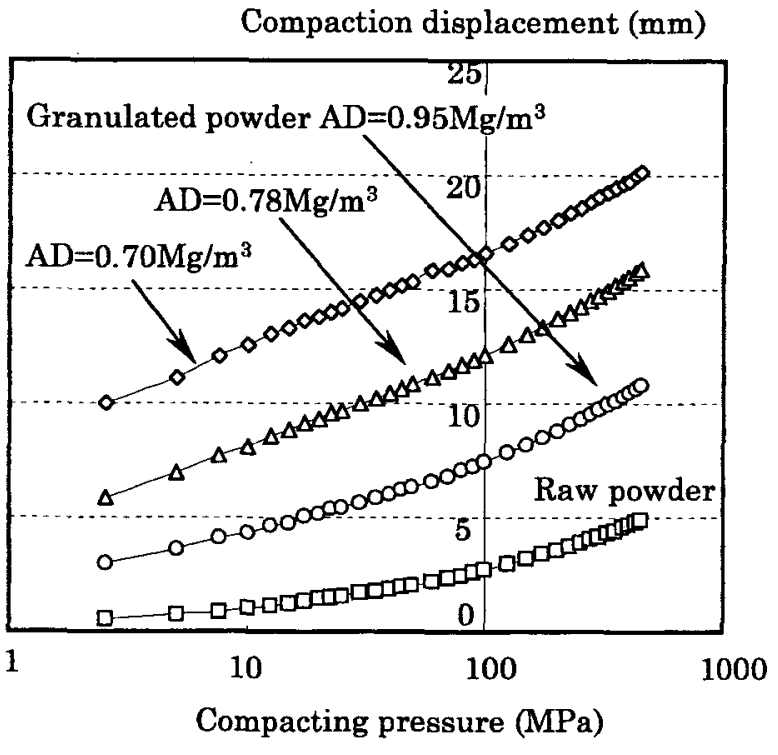

Fig.2 Change in compaction displacement in compacting raw powder and various granulated ones.

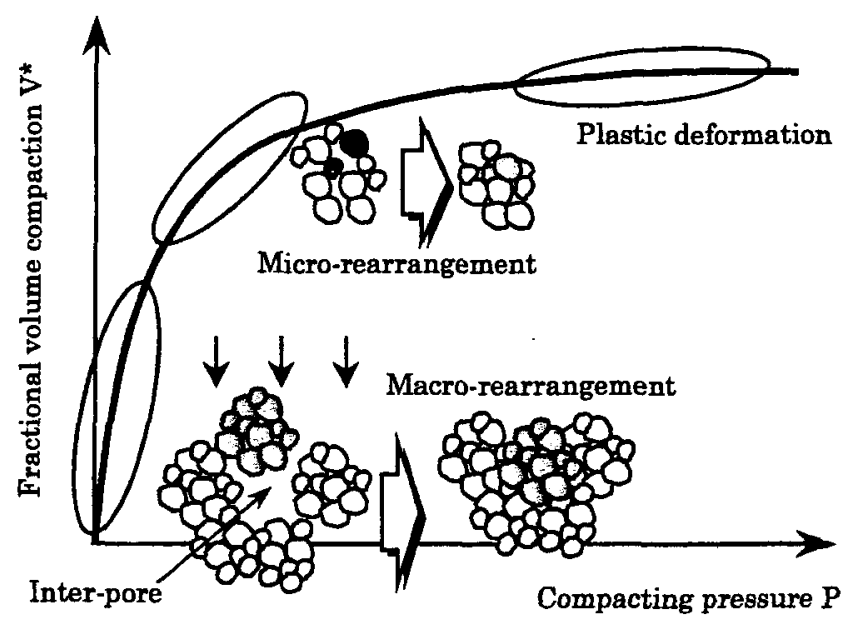

(b)

Fig.3 Schematic of compaction model in consolidating powders. (a) Conventional model (b) Proposed model in this work. 
変形が生じるまでの低圧力域では(a) と同様に主に粒子再配列 機構が生じるが,これは(1)金型内に造粒粉末を充填した際に 造粒粉末間に生じる空隙 (Inter-pore)を埋めるように造粒粉末 自身が移動する「マクロな粒子再配列」と，(2)造粒粉末内部 に存在する空隙 (Intra-pore) 閉鎖するように造粒粉末を構成 する 1 次粒子粉末の移動・再配列による「ミク口な粒子再配 列」に分類できる。そそして両機構が進行して粒子間の空隙が 埋められると, 压縮成形圧力が造粒粉末を構成する 1 次粒子 粉末に付加されて粒子の塑性変形あるいは破碎現象が生じる. 但し，Fig.2に示した压縮変位量と粉末のAD值の関係からマ クロな粒子再配列機構がより低い压力域で進行すると考えら れる。

3.2 修正 Cooper-Eaton 圧縮式による解析結果

次に，上記の造粒粉末の圧密機構を考慮した修正 CooperEaton圧縮式を提案しっこれを用いて造粒粉末の圧密化挙動解 析を行なった，具体的には，マクロ粒子再配列㧍よびミクロ 粒子再配列は従来の粒子再配列と同様の圧縮曲線で整理でき ると考え，(2)式に示すような 3 項の指数関数の線形和からな る修正式の適用を試みた。

$$
\begin{aligned}
\mathrm{V}^{*}= & \frac{\mathrm{V}(0)-\mathrm{V}(\mathrm{p})}{\mathrm{V}(0)-\mathrm{V}(\infty)}=\mathrm{a}(\mathrm{r} 1) \exp (-\mathrm{k}(\mathrm{r} 1) / \mathrm{P}) \\
& +\mathrm{a}(\mathrm{r} 2) \exp (-\mathrm{k}(\mathrm{r} 2) / \mathrm{P})+\mathrm{a}(\mathrm{p}) \exp (-\mathrm{k}(\mathrm{p}) / \mathrm{P})
\end{aligned}
$$

$\mathrm{a}(\mathrm{r} 1), \mathrm{k}(\mathrm{r} 1)$; Coefficient of macro-rearrangement $a(r 2), k(r 2)$; Coefficient of micro-rearrangement $a(p), k(p) \quad ;$ Coefficient of plastic deformation $(\mathrm{a}(\mathrm{r} 1)+\mathrm{a}(\mathrm{r} 2)+\mathrm{a}(\mathrm{p})=1)$

計算方法は従来の 2 項からなる計算プログラムにおいてマク 口粒子再配列の項を追加し, 粉末の圧縮データを用いて非線
形最小2乗法によって式中の各パラメータを算出した。なお， マクロ粒子再配列が最も低い加压領域で生じる上考之，右辺 第 1 項をマク口粒子再配列, 第 2 項をミク口粒子再配列, そし て第3 項を塑性変形・破砕現象に上るものとした。

先ず，造粒粉末の圧密化挙動に及ぼす粒子再配列上塑性変 形の奇与度を評価すべく，(1)式抢よび (2) 式により算出した $\mathrm{a}$ 值 $(\mathrm{a}(\mathrm{r})$; 粒子再配列， $\mathrm{a}(\mathrm{p})$; 塑性変形) と粉末の $\mathrm{AD}$ 值との関 係を Fig.4に示す。 (a)は今回提案した3項モデルに基づく修正 式による計算結果であり，(b)は従来の Cooper-Eaton式を用い た結果である。なお，西図は同じ圧縮データを用いて計算し た結果である。これに見るように修正式によれば、マクロお よびミクロ粒子再配列と塑性変形のそれぞれによる粉末の圧 密化挙動への寄与度を分離することができる，その結果，マ ク口粒子再配列機構の寄与度を示す $\mathrm{a}(\mathrm{r})$ 値は 2 項モデルでの 計算結果と同様に，造粒粉末の AD 值が増加するに従ってほ ほ直線的に減少する。一方, ミク口粒子再配列の寄与度を示 す $\mathrm{a}(\mathrm{r} 2)$ 值に関しては, $\mathrm{a}(\mathrm{r} 1)$ 值の傾向とは逆に $\mathrm{AD}$ 值の増加に 伴ない増大している。この結果は造粒粉末の $\mathrm{AD}$ 値と造粒粉 末内のIntra-pore量に起因している. 前述したようにミクロな 粒子再配列とは原料粉末同士がPVAバインダーによって結合 してできた造粒粉末内部のIntra-poreを閉鎖するように1次粒 子粉末が移動・再配列する現象を意味している。のえに造粒 粉末中のIntra-pore量が多いほど圧密化過程におけるa(r2)值は 增加する。一方，前報で記載したように造粒過程におけるバ インダーの結合が強固になると, 造粒化が淮行して内部の Intra-pore 量が減少し，より緻密で粗大な球状の造粒粉末が得 られる。そ結果，造粒粉末の AD值が低下する。つまり，造 粒化が進行すると造粒粉末の AD 值は低下し, 粉末内部の Intra-pore 量も低隇する．以上のことから造粒粉末の $\mathrm{AD}$ 值が

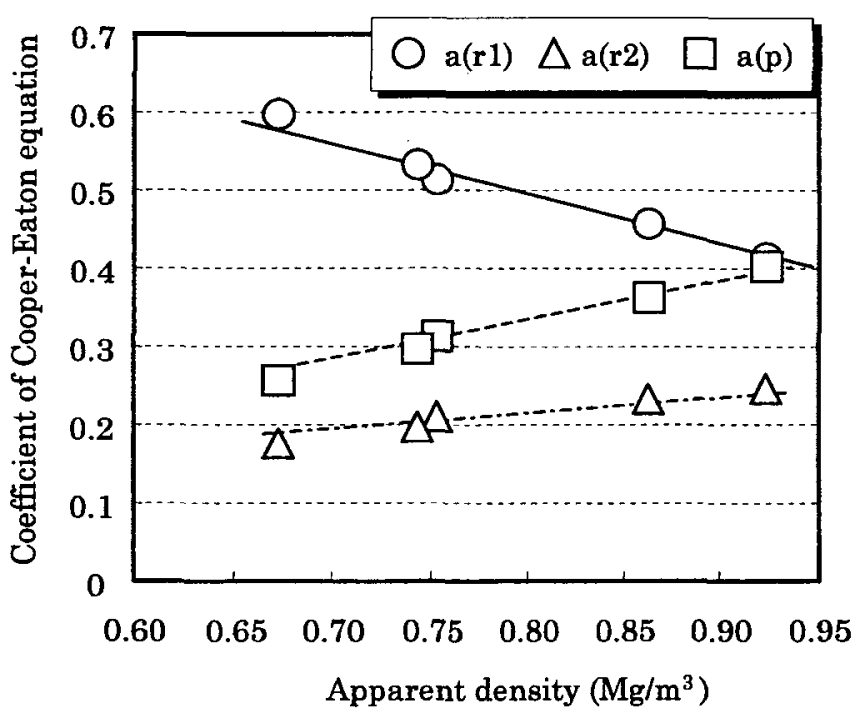

(a)

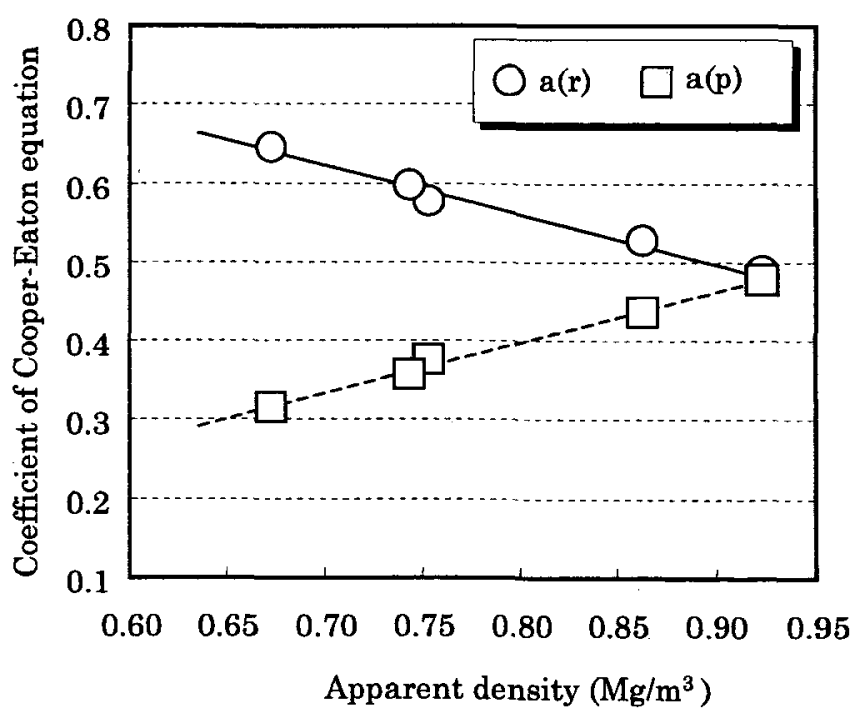

(b)

Fig.4 Relationship between apparent density of powders and parameter a of rearrangement and plastic deformation calculated by modified Cooper-Eaton equation compared with conventional one. (a) Modified equation (b) Conventional equation. 
減少すると, Inter-pore 量が増えるためにマクロ粒子再配列の 奇与率は増加するが, 逆にIntra-pore 量が滅少するためにミク 口粒子再配列の寄与率が低下すると考えられる。また，いず れの造粒粉末においても $\mathrm{a}(\mathrm{r} 2)$ 值に比べて $\mathrm{a}(\mathrm{r} 1)$ 值が大きい。こ れは平均粒子径と $\mathrm{AD}$ 值から算出した粉末充填時の Inter-pore 量が約 30〜40vol.\%であるのに対して，造粒粉末の断面組織 観察結果より求めた粉末内部の Intra-pore量が約8～15vol.\%と 小さいためにマクロ粒子再配列の寄与度を表す $\mathrm{a}(\mathrm{r} 1)$ 值が大き くなったと考えられる，以上の結果より，造粒粉末を圧粉成 形する際の粒子再配列による緻密化挙動では造粒粉末自身の 移動によるマク口粒子再配列機構が主な支配因子であるとい える。

3.3 修正 Cooper-Eaton 圧縮式の適合性の検証

造粒粉末の圧密化過程における粒子再配列と塑性変形の開 始領域について修正式と従来式を用いて評価した．Fig.5に $\mathrm{AD}$ 值に対する各圧密化機構の開始相当圧力パラメー夕 $\mathrm{k}$ 值の 変化を示す. (a), (b) は粒子再配列抢よび塑性変形の各機構の 開始相当圧力である.AD値の違いによって多少の差はあるも のの, 修正式によればk(r1); 5.9 7.8MPa, $\mathrm{k}(\mathrm{r} 2) ; 22.5 \sim 31.4 \mathrm{MPa}$, $\mathrm{k}(\mathrm{p}) ; 323.4 \sim 362.6 \mathrm{MPa}$ となり, マクロ粒子再配列は極低圧力域 で生じ, 続くミクロ粒子再配列機構も 30MPa 程度で完了す る. $\mathrm{k}(\mathrm{p})$ 值からは 1 次粒子粉末の塑性変形がいずれも $350 \mathrm{MPa}$ 付近で開始していることを意味しているが，この值は本試料 粉末を固化した合金の圧縮耐力 $\left(\sigma_{\mathrm{c}}=344 \mathrm{MPa}\right)$ とほほ一致して おり，実際に粉末を圧縮した際の塑性変形能を精度よく推定 している。一方, 従来式によれば $\mathrm{k}(\mathrm{r})$ 值 ; 6.9 11.8MPa とな $\eta$, 修正式での結果と同等であるが, $\mathrm{k}(\mathrm{p})$ 值は $117.6 \sim 147 \mathrm{MPa}$ と修正式による值に比べて $200 \mathrm{MPa}$ 程度小さい。これは従来 式ではミク口粒子再配列と塑性変形との奇与率の分離が困難

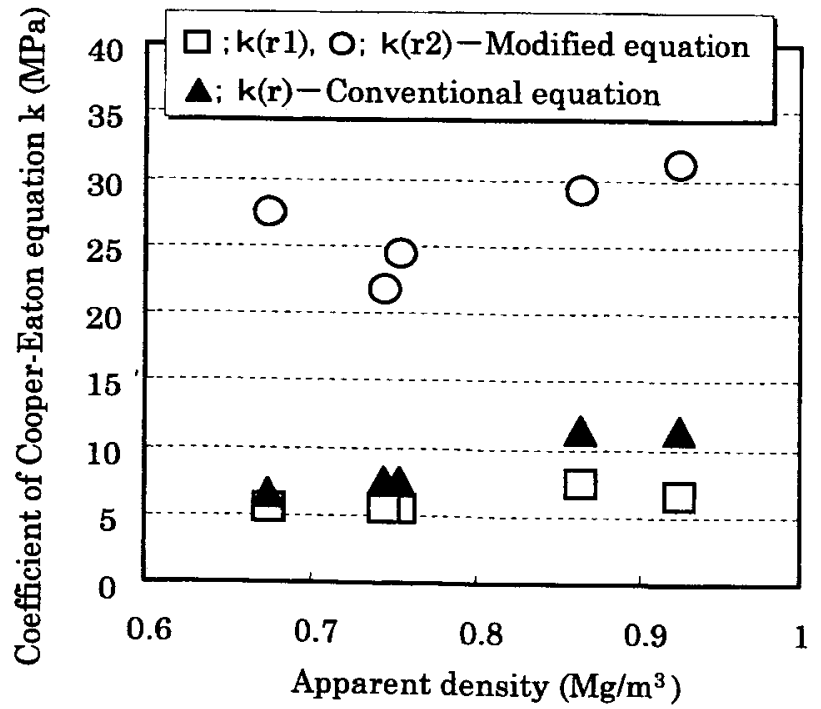

(a) であるために両者が重複して計算され，その結果，k(p) 值は 修正式によって算出した値に比べて小さくなったと考えられ る、以上の結果より今回提案した修正式によれば,マクロ・ミ クロ粒子再配列機構の開始度合いのみならず, 算出した各圧 密機構の開始圧力も高い精度で推定できるこ上から本修正式 の妥当性が検証された。

さらに，実際に圧縮成形した試料の体積圧縮率の測定值 $\left(\mathrm{V}_{\mathrm{m}}{ }_{\mathrm{m}}\right)$ と各圧縮式により算出した体積圧縮率 $\left(\mathrm{V}_{\mathrm{c}}{ }^{*}\right)$ との差の自乗

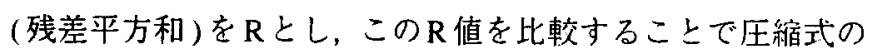
適合性を検証した。その結果を Fig.6に示す。ここでは，Fig.2 に示した 3 種類の造粒粉末についてそ机ぞれ 5 回の圧縮試験 を行ない，従来式と修正式によって R 値を算出してそれぞれ の平均値を求めた。いずれの造粒粉末に扔いても残差平方和

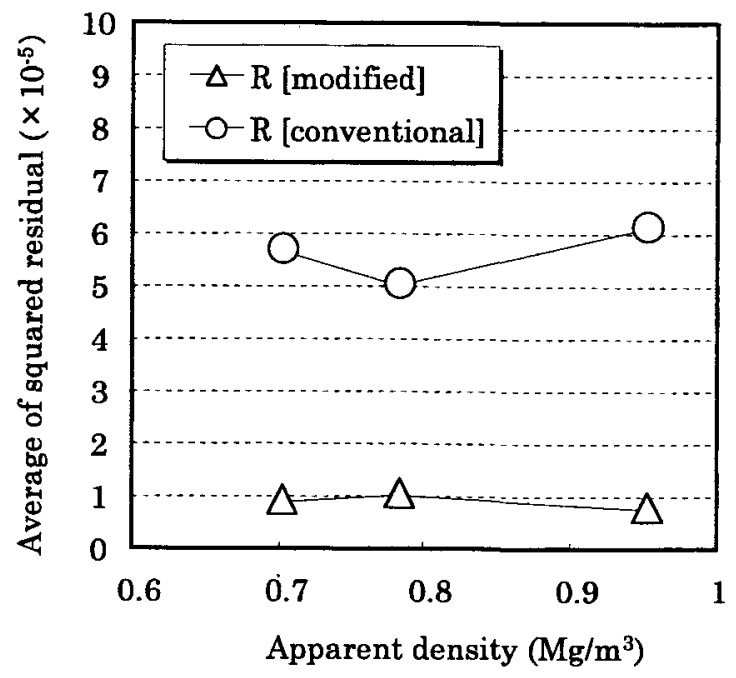

Fig.6 Comparison of conformity of each compaction equation.

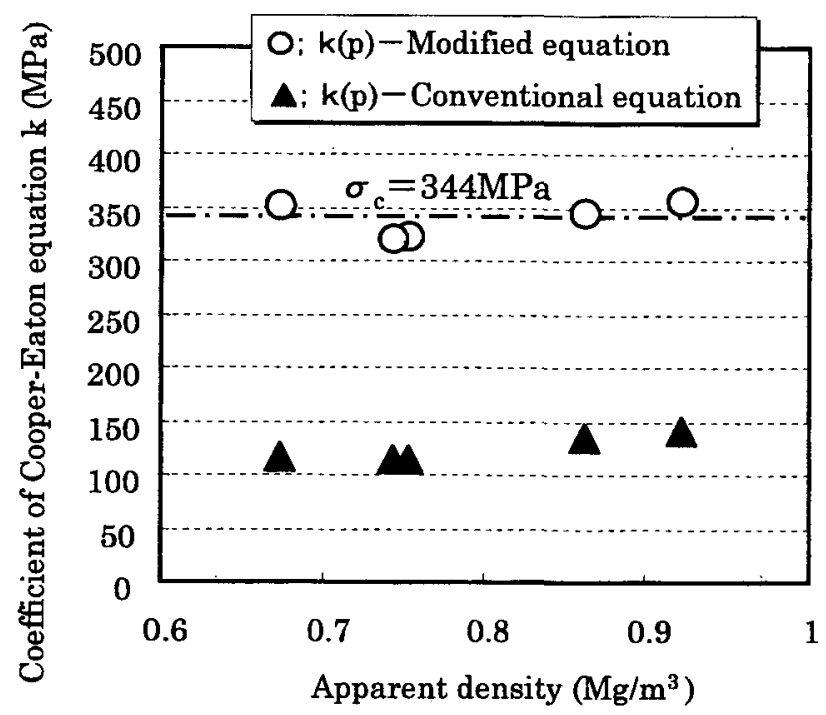

(b)

Fig.5 Relationship between apparent density of powders and parameter $\mathrm{k}$ of rearrangement and plastic deformation calculated by modified Cooper-Eaton equation compared with conventional one. (a) Rearrangement (b) Plastic deformation. 
の值は修正式を用いた場合が小さいことから修正式がより高

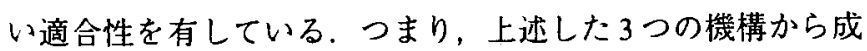
る造粒粉末の圧密化挙動モデルが妥当であるといえる．

\section{4 体皘圧縮率に及ほす各圧密化機構の影響}

修正式により算出した各パラメータを用いて，圧縮圧力 784MPaを負荷した際の造粒粉末の全体積圧縮率に扔けるマク 口およびミクロ粒子再配列の比率を整理した結果を Fig.7に 示す. Fig.4(a)に記載の通り AD值が減少すると造粒粉末間の Inter-pore 量が増加するために造粒粉末の移動・再配列現象が 進行し易くなり $\mathrm{a}(\mathrm{r} 1)$ 值が増大する，その結果，マクロ粒子再 配列による体積圧縮率 $\mathrm{V}(\mathrm{r} 1)$ の比率が増加する，逆に $\mathrm{AD}$ 值が 減少すると造粒粉末が緻密化するために粉末内部での 1 次粒 子粉末の移動・再配列が進行し難くなり，ミクロ粒子再配列 による体積圧縮率 $\mathrm{V}(\mathrm{r} 2)$ の寄与度は低下する。また，V(r1) 値 はV(r2)値の2〜3倍と大きく，この結果も3.2 項で記載したよ うに造粒粉末内の Intra-pore 量 (約 8 15vol.\%)に対して, 充填 時の造粒粉末間の Inter-pore 量 (約 30〜 40vol.\%) が2 3 倍程度 大きいことに起因すると考えられる。

次に, マクロ拉よびミクロ粒子再配列と塑性変形の全圧密 過程に対する寄与率について，体積圧䌅率 $\mathrm{V}$ の対数と圧粉圧 力の逆数1/Pの関係を Fig.8に示す. (a)〜(c)は順に，マクロ粒 子再配列，ミクロ粒子再配列，望性変形による体積圧縮率の 対数と $1 / \mathrm{P}$ との関係であり，いずれも直線関係を有している． これは前記の(2)式から判るように，体皘圧縮率 $\mathrm{V}$ の対数が右 辺の各項に対して $1 / \mathrm{P} の$ 関数となる結果, $1 / \mathrm{P}$ との直線関係と して表現できる。(a)のマクロ粒子再配列の寄与率に関して $\mathrm{AD}$ 值が隇少するにつれて体積圧綟率は全圧粉圧力域において 増加しており，各直線の傾き，つまり $\mathrm{k}(\mathrm{r})$ 值はほほ同じであ る. (b)のミク口粒子再配列の奇与率について，低加圧領域で は体皘圧縮率の值に多少の差異はあるものの, 高圧力域では 圧密化への寄与度に顕著な差違は見られない. 一方, (c)の塑 性変形の寄与率に関して圧密化に有効な体皘圧縮率 0.01 以上

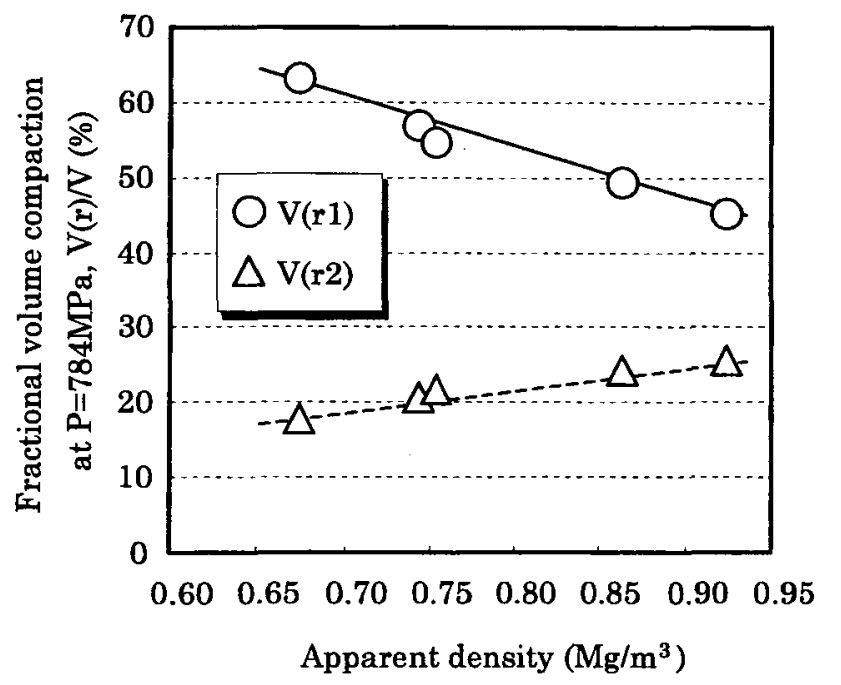

Fig.7 Relationship between apparent density and fractional volume compaction under consolidating pressure of $784 \mathrm{MPa}$.

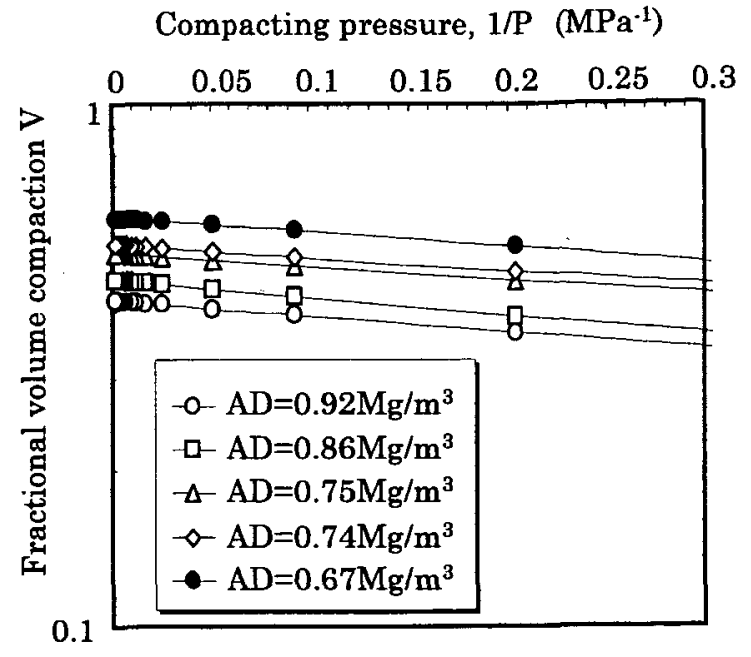

(a)

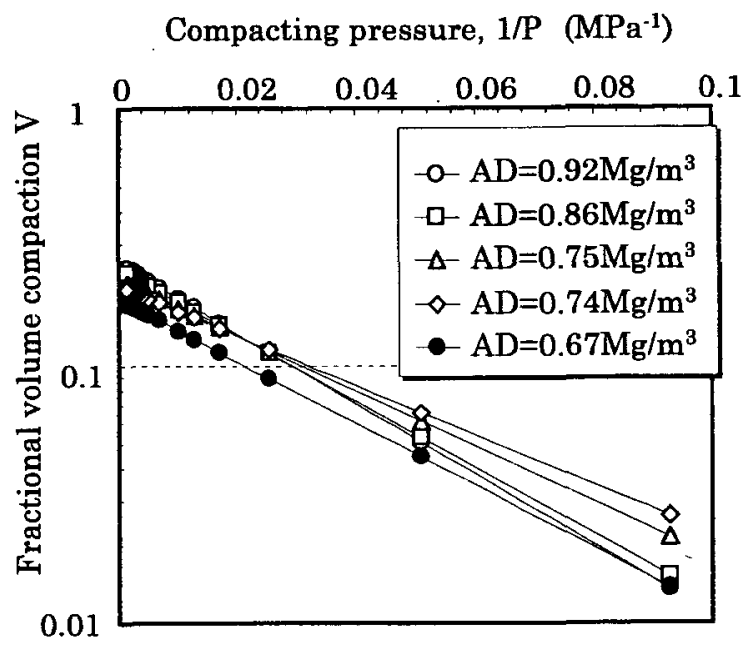

(b)

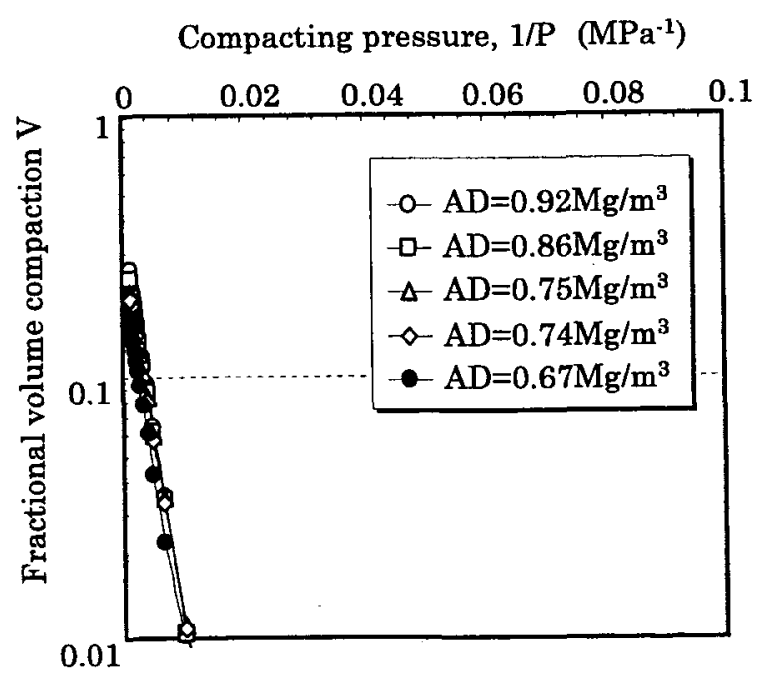

(c)

Fig.8 Effects of each compaction factor on fractional volume compaction in modified equation. (a) Macro-rearrangement (b) Micro-rearrangement (c) Plastic deformation. 
の範囲では, 各造粒粉末の体積圧縮率が粉末の AD 值に関係 なくほぼ一つの直線として整理できる. 本来, 塑性変形は1次 粒子粉末の降伏点や硬さ，剛性等に直接依存することから造 粒粉末を構成する1次粒子粉末が同一である限り，たとえ $\mathrm{AD}$ 值が異なっても塑性変形による全圧密に対する奇与率は同等 となる，そのため，(c)に示したように塑性変形による体積圧 縮率のデータは AD 值に依存することなく，全て一つの直線 上に整理できると考えられる。

\section{4 結 論}

湿式造粒アルミニウム合金粉末の圧密化機構に及ほす寸粉体 特性の影響について Cooper-Eaton 圧縮式を用いて検討すると 共に, 造粒粉末の圧密化挙動解析に適した修正式を提案し, この妥当性を検証した. 本研究で得られた結果を以下に示す。

(1) 造粒粉末の外観・断面組織観察およびCooper-Eaton圧縮式 による圧密化挙動解析の結果, 造粒粉末の圧密化挙動は次 の3 機構からなるモデルであることを提案した。

(1) 充填時の造粒粉末間の空隙(Inter-pore)を埋めるように粉末 が移動するマクロな粒子再配列

(2) 造粒粉末内部に存在する空腙(Intra-pore)を閉鎖するように 造粒粉末を構成する1次粒子粉末の移動によるミクロな粒 子再配列

(3) 圧縮成形圧力による1次粒子粉末の塑性変形
（2）全体積圧縮率に対するマクロな粒子再配列機構の割合はミ クロな粒子再配列機構による場合に比べて 2 3 倍と大き く，かつそれによる圧密化挙動は6－8MPa 程度の極めて 低い加圧領域に扔いて生じる。

(3) 修正式による圧密化挙動解析の結果, いずれの造粒粉末の $\mathrm{k}(\mathrm{p})$ 值も約 $350 \mathrm{MPa}$ となり, 試料粉末合金の圧縮耐力 $\left(\sigma_{\mathrm{c}}=344 \mathrm{MPa}\right)$ とほほ一致しており, 光らに従来式に比べて 修正式を用いた場合の残差平方和が小さいことから今回提 案した 3 項モデルに基づく修正式が妥当であるといえる。

\section{文献}

1) K.Kondoh et al.: "Wear Property of Powder Forged Aluminum Alloy", Proceeding of 1993 Powder Metallurgy World Congress, Kyoto, Japan Society of Powder and Powder Metallurgy, (1993)339-343.

2）近藤ほか："湿式造粒処理を施したアルミニウム合金粉末 の粉体特性に及ほすずインダー条件の影響", 粉体扔よび粉 末治金, 46(1999).

3）橋本ほか: "アトマイズ低合金鋼粉の圧縮成形式/鉄鋼の粉 末治金における新しい展開", 日本鉄鋼協会・粉粒体工学 フォーラム, 東京, (1996)39-45.

4) A.R.Cooper and L.E.Eaton: "Compaction Behavior of Several Ceramics Powders", J. Amer. Ceram. Soc., 45(1962)97-101. 